\title{
Mechanisms and Significance of Eryptosis, the Suicidal Death of Erythrocytes
}

\author{
Florian Lang Syed M. Qadri \\ Department of Physiology, University of Tübingen, Tübingen, Germany
}

\section{Key Words}

Apoptosis · Red blood cells · Anemia - Sepsis - Diabetes ·

Renal insufficiency $\cdot$ Erythropoietin $\cdot$ Malaria

\begin{abstract}
Eryptosis, the suicidal death of erythrocytes, is characterized by erythrocyte shrinkage, blebbing, and phospholipid scrambling of the cell membrane. Eryptosis is triggered by increased cytosolic $\mathrm{Ca}^{2+}$ activity, which may result from $\mathrm{Ca}^{2+}$ entry through $\mathrm{PGE}_{2}$-activated $\mathrm{Ca}^{2+}$-permeable cation channels. The $\mathrm{Ca}^{2+}$ sensitivity of the scrambling machinery is enhanced by ceramide, which is formed by an acid sphingomyelinase, an enzyme stimulated by platelet-activating factor. Eryptosis is enhanced in a variety of clinical conditions such as sickle-cell anemia, $\beta$-thalassemia, glucose-6-phosphate dehydrogenase deficiency, hereditary spherocytosis, paroxysmal nocturnal hemoglobinuria, myelodysplastic syndrome, phosphate depletion, iron deficiency, sepsis, hemolytic uremic syndrome, renal insufficiency, diabetes, malaria, mycoplasma infection, and Wilson's disease. Eryptosis is enhanced in mouse models of sickle cell anemia and thalassemia, as well as in mice lacking functional annexin 7, cGMP-dependent protein kinase type I, AMP-activated protein kinase, Janus kinase 3, anion exchanger 1, adenomatous polyposis coli, or Klotho. Eryptosis is triggered by osmotic shock, oxidative stress, energy depletion, hyperthermia, and
\end{abstract}

a myriad of small molecules. Eryptosis is inhibited by a variety of substances including nitric oxide and catecholamines. Erythropoietin counteracts eryptosis in part by inhibiting the $\mathrm{Ca}^{2+}$-permeable cation channels. Excessive erythropoietin concentrations lead, however, to formation of erythrocytes, which are particularly sensitive to eryptotic stimuli. Accelerated eryptosis may be compensated by enhanced erythropoiesis, which is apparent from reticulocytosis. If the compensation is not sufficient, clinically relevant anemia develops. Beyond that, adhesion of eryptotic erythrocytes to the vascular wall may lead to impairment of microcirculation.

Copyright $\odot 2012$ S. Karger AG, Basel

\section{Introduction}

Mature, circulating erythrocytes undergo senescence with subsequent clearance of the aged erythrocytes, which limits the life span to approximately 100-120 days (for references see [1]). Erythrocyte senescence involves binding of hemichromes to band 3, clustering of band 3, and deposition of complement $\mathrm{C} 3$ fragments and antiband 3 immunoglobulins.

Prior to senescence, erythrocytes may, however, experience injury which compromises their integrity and thus triggers suicidal erythrocyte death or eryptosis [1]. Ery-

\section{KARGER \\ Fax +4161306 1234 E-Mail karger@karger.ch} www.karger.com
(C) 2012 S. Karger AG, Basel 0253-5068/12/0333-0125\$38.00/0
Prof. Dr. Florian Lang

Physiologisches Institut der Universität Tübingen Gmelinstrasse 5

DE-72076 Tübingen (Germany)

Tel. +49 7071297 2194, E-Mail florian.lang@ uni-tuebingen.de 
ptosis is similar to apoptosis. However, erythrocytes lack nuclei and mitochondria, important organelles in the machinery executing apoptosis. Accordingly, erythrocytes lack several features of apoptosis including mitochondrial depolarization and condensation of nuclei. However, eryptosis shares several other features of apoptosis, such as cell shrinkage, membrane blebbing, and cell membrane scrambling, leading to phosphatidylserine exposure at the cell surface [1].

In this review, mechanisms regulating, triggering, and inhibiting the suicidal erythrocyte death or eryptosis are briefly described. As only 30 references are allowed for this review, only the most recent papers on eryptosis are cited. Earlier references are available in a previous review [1]

\section{Mechanisms Triggering Eryptosis}

$\mathrm{Ca}^{2+}$

Eryptosis is elicited by an increase in cytosolic $\mathrm{Ca}^{2+}$ activity [1]. $\mathrm{Ca}^{2+}$ stimulates cell membrane scrambling and activates the cysteine endopeptidase calpain, an enzyme that degrades cytoskeletal proteins thus causing cell membrane blebbing [1]. $\mathrm{Ca}^{2+}$ further activates $\mathrm{Ca}^{2+}$-sensitive $\mathrm{K}^{+}$channels with subsequent efflux of $\mathrm{K}^{+}$, hyperpolarization of the cell membrane, and $\mathrm{Cl}^{-}$exit due to enhanced electrical gradient. The cellular loss of $\mathrm{KCl}$ is followed by the exit of osmotically obliged water, thus leading to cell shrinkage [1].

The increase in cytosolic $\mathrm{Ca}^{2+}$ activity may result from activation of nonselective cation channels mediating $\mathrm{Ca}^{2+}$ entry [1]. The molecular identity of the cation channels is incompletely understood, but presumably involves transient receptor potential channel 6 [1]. The cation channels are activated by a wide variety of challenges including osmotic shock, oxidative stress, and $\mathrm{Cl}^{-}$removal [1]. Hyperosmotic shock is affected at least in part by stimulation of cyclooxygenase with generation of prostaglandin $\mathrm{E}_{2}$, which in turn activates the cation channel [1].

\section{Ceramide}

The $\mathrm{Ca}^{2+}$ sensitivity of erythrocyte cell membrane scrambling and cell shrinkage is enhanced by ceramide, which similarly stimulates eryptosis [1]. Ceramide may be produced from cell membrane sphingomyelin by sphingomyelinase, which may either be expressed in erythrocytes or released into plasma and act from outside [1]. Ceramide formation may be stimulated by plateletactivating factor (PAF), which is in turn formed from cell membrane lipids by a phospholipase [1]. The phospholipase is activated and thus PAF released following osmotic erythrocyte shrinkage. Erythrocytes do express PAF receptors, and exposure of erythrocytes to PAF stimulates ceramide formation [1]. Gene-targeted mice lacking PAF receptors are insensitive to the effects of PAF on ceramide formation and eryptosis [1].

\section{Additional Mechanisms}

A wide variety of further mechanisms and challenges participate in the triggering or regulation of eryptosis. Eryptosis is stim- ulated by energy depletion, which is at least partially affected by activation of protein kinase C [1].

Eryptosis is further activated following oxidative stress or following impairment of antioxidative defense [1]. Oxidative stress activates the $\mathrm{Ca}^{2+}$-permeable cation channels, thus stimulating $\mathrm{Ca}^{2+}$ entry. Oxidative stress further activates erythrocyte $\mathrm{Cl}^{-}$ channels, which contributes to eryptotic cell shrinkage. In addition, oxidative stress activates caspases, which could stimulate eryptosis, but are not required for eryptosis following $\mathrm{Ca}^{2+}$ entry [1].

Eryptosis is regulated by a variety of kinases, such as cGMPdependent protein kinase type I, AMP-activated kinase, and Janus kinase 3 (table 1). A powerful inhibitor of eryptosis is nitric oxide, which renders erythrocytes partially resistant against the eryptotic effects of increased cytosolic $\mathrm{Ca}^{2+}$ activity (table 2).

\section{Diseases Associated with Enhanced Eryptosis}

Excessive eryptosis is observed in a variety of diseases (table 1). Several genetic defects of hemoglobin synthesis, such as sickle cell anemia and thalassemia; erythrocyte enzymes, such as glucose-6-phosphate dehydrogenase deficiency; or carriers, such as the anion exchanger 1 , are associated with enhanced vulnerability of the erythrocytes against stimulators of eryptosis [1]. In one family with excessive eryptosis, a mutation of GLUT1 was observed, turning the glucose carrier into a $\mathrm{Ca}^{2+}$-permeable cation channel. More importantly, enhanced eryptosis is observed in common diseases, such as iron deficiency, diabetes, and renal insufficiency. As eryptosis is highly sensitive to temperature and triggered by hyperthermia (table 2), eryptosis is expected to occur in fever. Excessive eryptosis is observed in sepsis and in hemolytic uremic syndrome. Hemolytic disorders analyzed thus far have been shown to be paralleled by excessive eryptosis. It appears that hemolysis is only the tip of the iceberg and that in most affected erythrocytes parallel eryptosis prevents lysis with subsequent release of hemoglobin into the plasma [1].

Eryptosis is triggered following invasion of the malaria pathogen Plasmodium. Following entry into the erythrocyte, the pathogen induces oxidative stress, which activates the $\mathrm{Ca}^{2+}$-permeable cation channels and thus triggers eryptosis. The suicidal death is followed by the clearance of the infected erythrocyte together with the pathogen, thus counteracting parasitemia. At least in mice, several substances triggering eryptosis have been found to favorably influence the clinical course of the disease [1].

Enhanced eryptosis is observed in newly formed erythrocytes of healthy individuals returning from high 
altitudes or space flight, a phenomenon called 'neocytolysis'. The enhanced eryptosis in patients with paroxysmal nocturnal hemoglobinuria and myelodysplastic syndrome preferably affects lighter and, thus, presumably younger erythrocytes, pointing to neocytolysis in those diseases [2]. At this stage, the mechanisms underlying neocytolysis have remained elusive [1]. Notably, a similarly enhanced susceptibility to eryptosis is observed in erythrocytes drawn from erythropoietin-overexpressing transgenic mice [1]. Possibly, erythropoietin stimulates in progenitor cells the expression of genes sensitizing the erythrocytes to eryptotic challenges. As a result, erythrocytes undergo, in part, suicidal death as soon as the erythropoietin concentrations decline. The premature clearance of erythrocytes may serve to normalize blood erythrocyte concentration as soon as it is no longer needed and the plasma erythropoietin concentrations fall. Accordingly, neocytolysis may accelerate the negative feedback regulation of erythrocyte abundance, which otherwise would take 120 days. Additional experimental efforts are needed to prove or disprove this speculation.

Excessive eryptosis has also been observed in several gene-targeted mice, thus pointing to molecules involved in the regulation of erythrocyte survival (table 1). Similar to human disease, mice with defective hemoglobin (sickle cell, thalassemia) suffer from accelerated suicidal erythrocyte death. A mouse model resembling sickle cell anemia is the A7 mouse. Similar to sickle cell trait erythrocytes, A7-deficient erythrocytes generate excessive $\mathrm{PGE}_{2}$, which in turn activates the cation channels with subsequent eryptosis [3]. Eryptosis is inhibited by cGMPdependent protein kinase type I, AMP-activated protein kinase. Accordingly, gene-targeted mice lacking one of those kinases suffer from accelerated eryptosis. Similarly, endothelin inhibits eryptosis, and mice lacking the endothelin B receptor suffer from accelerated eryptosis. Knockout of the anion exchanger 1 is followed by severely enhanced eryptosis and anemia despite excessive formation of new erythrocytes. As pointed out above, mice overexpressing erythropoietin harbor erythrocytes particularly sensitive to eryptosis. In Klotho deficiency, the excessive formation of $1,25(\mathrm{OH})_{2} \mathrm{D}_{3}$ leads to moderately enhanced eryptosis. In adenomatous polyposis coli-deficient mice, the appearance of intestinal tumors is paralleled by increased eryptosis. In some mice, the erythrocytes may be resistant to specific stimulators of eryptosis, such as mice expressing decreased levels of phosphoinositide-dependent kinase 1 or mice lacking the PAF receptor or transient receptor potential channel 6 (table 1).
Table 1. Diseases associated with enhanced eryptosis and mouse models associated with enhanced or decreased eryptosis

\section{Effective through Ref \\ $\mathrm{Ca}^{2+}$ Cer. other}

Diseases associated with accelerated eryptosis

Iron deficiency

Phosphate depletion

Neocytolysis

Sepsis

Hemolytic anemia

Hemolytic uremic syndrome

Renal insufficiency

Diabetes

Malaria

Sickle-cell disease

Thalassemia

G6PD deficiency

Wilson's disease

AE1 mutation

GLUT1 mutation

$+\quad 1$

$+\quad 1$

$+\quad 1$
$+\quad 1$

$+\quad+\quad+\quad 1$

$+\quad+\quad 1$

$\begin{array}{lll}+ & + & 1 \\ + & & 1\end{array}$

$+\quad 4,5$

$+\quad 1,6,7$

Paroxysmal nocturnal hemoglobinuria

Myelodysplastic syndrome

Hereditary spherocytosis

Mycoplasma infection

Hyperthermia

$+\quad 1$

, 8

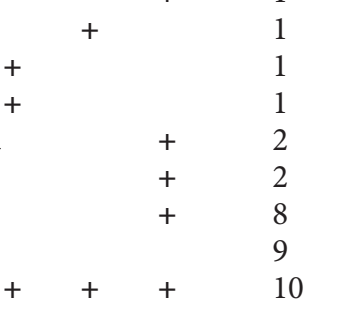

Mouse models with enhanced eryptosis

Defective hemoglobin

(sickle cell, thalassemia)

Annexin A7 deficiency

cGKI deficiency

AMPK deficiency

Endothelin B receptor deficiency

AE1 deficiency

APC deficiency

Klotho deficiency

EPO excess

$\begin{array}{lll}+ & & 1 \\ + & & 3 \\ + & & 1 \\ + & & 1 \\ + & & 12 \\ + & & 1 \\ & + & 13 \\ + & & 1 \\ + & & 1\end{array}$

Mouse models with reduced eryptosis

PDK1 deficiency

TRPC6 deficiency

PAF receptor deficiency

JAK3 deficiency

$\begin{array}{llll}+ & & & \\ + & & & 1 \\ & + & & 1 \\ & & & 1 \\ & & & 11\end{array}$

G6PD = Glucose-6-phosphate dehydrogenase; $\mathrm{AE1}=$ anion exchanger 1 ; cGKI = cGMP-dependent protein kinase type I; $\mathrm{AMPK}=\mathrm{AMP}$-activated protein kinase; JAK3 = Janus kinase 3; $\mathrm{APC}=$ adenomatous polyposis coli; $\mathrm{EPO}=$ erythropoietin; PDK1 = phosphoinositide-dependent kinase 1; TRPC6 = transient receptor potential channel 6. Mechanisms: $\mathrm{Ca}^{2+}=$ stimulation of $\mathrm{Ca}^{2+}$ entry; Cer. = stimulation of ceramide formation; other = inhibition of ATP depletion, etc. To limit the number of references, preference is given to reviews. 
Table 2. Stimulators and inhibitors of eryptosis

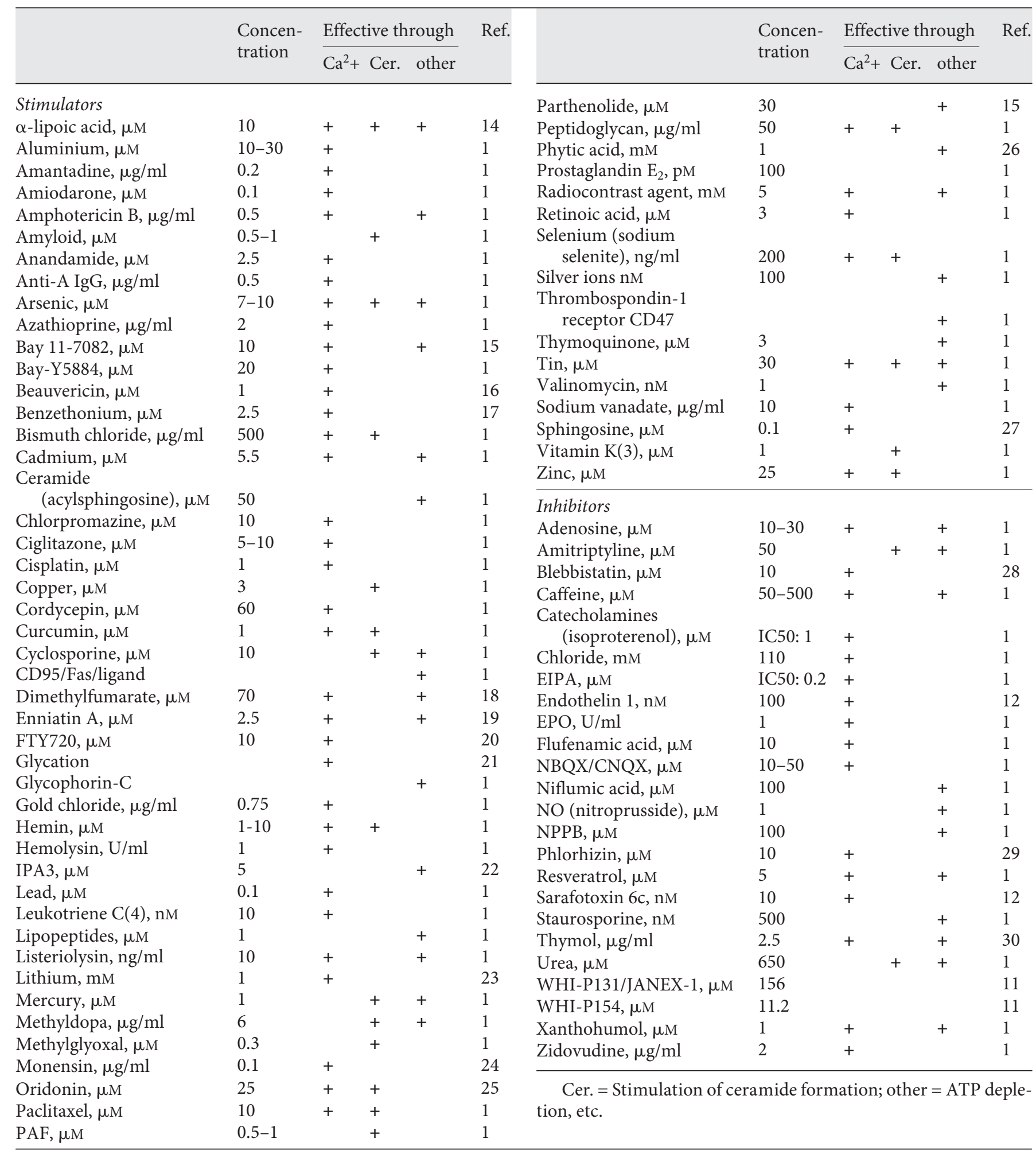


Eryptosis is triggered by a wide variety of small molecules (table 2). The substances are effective by increased cytosolic $\mathrm{Ca}^{2+}$ activity, stimulation of ceramide formation, and/or further mechanisms such as ATP depletion, oxidative stress, and/or caspase 3 activation (table 2). A variety of substances inhibit eryptosis. Most of those substances directly or indirectly inhibit $\mathrm{Ca}^{2+}$ entry. On the other hand, some substances decrease the $\mathrm{Ca}^{2+}$ sensitivity of cell membrane scrambling.

\section{Consequences of Eryptosis}

Phosphatidylserine-exposing erythrocytes are rapidly cleared from circulating blood. They bind to respective receptors of macrophages and are then engulfed and degraded [1]. As a result, excessive eryptosis leads to anemia unless the enhanced loss of erythrocytes is compensated by similarly enhanced formation of new erythrocytes. The formation of new erythrocytes is apparent from the percentage of reticulocytes. Thus, accelerated eryptosis may be apparent from reticulocytosis rather than anemia.

Phosphatidylserine-exposing erythrocytes further adhere to the vascular wall and may therefore impede microcirculation [1]. It is particularly intriguing to speculate that $\mathrm{PGE}_{2}$-stimulated excessive eryptosis leads to the breakdown of microcirculation in kidney medulla following acute renal failure.

\section{Conclusions}

Similar to apoptosis of nucleated cells, eryptosis is the suicidal death of mature erythrocytes. Eryptosis is accomplished by a complex machinery involving activation of ion channels, stimulation or inhibition of kinases, and formation of ceramide. Accelerated eryptosis is encountered in a wide variety of diseases and is stimulated by a large number of small molecules. Future experiments are expected to uncover additional triggers and inhibitors of eryptosis, as well as further signaling molecules contributing to the orchestration of the tightly regulated suicidal erythrocyte death.

\section{Disclosure Statement} close.

\section{References}

1 Lang F, Gulbins E, Lang PA, Zappulla D, Foller M: Ceramide in suicidal death of erythrocytes. Cell Physiol Biochem 2010;26: 21-28.

$\checkmark 2$ Basu S, Banerjee D, Ghosh M, Chakrabarti A: Erythrocyte membrane defects and asymmetry in paroxysmal nocturnal hemoglobinuria and myelodysplastic syndrome. Hematology 2010;15:236-239.

$\checkmark 3$ Lang E, Lang PA, Shumilina E, Qadri SM, Kucherenko Y, Kempe DS, Foller M, Capasso A, Wieder T, Gulbins E, Clemen CS, Herr C, Noegel AA, Huber SM, Lang F: Enhanced eryptosis of erythrocytes from gene-targeted mice lacking annexin A7. Pflügers Arch 2010;460:667-676.

4 Calderon-Salinas JV, Munoz-Reyes EG, Guerrero-Romero JF, Rodriguez-Moran M, Bracho-Riquelme RL, Carrera-Gracia MA, Quintanar-Escorza MA: Eryptosis and oxidative damage in type 2 diabetic mellitus patients with chronic kidney disease. Mol Cell Biochem 2011;357:171-179.

5 Maellaro E, Leoncini S, Moretti D, Del Bello B, Tanganelli I, De Felice C, Ciccoli L: Erythrocyte caspase-3 activation and oxidative imbalance in erythrocytes and in plasma of type 2 diabetic patients. Acta Diabetol 2011, E-pub ahead of print.

-6 Siraskar B, Ballal A, Bobbala D, Foller M, Lang F: Effect of amphotericin B on parasitemia and survival of Plasmodium bergheiinfected mice. Cell Physiol Biochem 2010;26: 347-354.

7 Bobbala D, Alesutan I, Föller M, Huber SM, Lang F: Effect of anandamide in Plasmodium berghei-infected mice. Cell Physiol Biochem 2010;26:355-362.

-8 Basu S, Banerjee D, Chandra S, Chakrabarti A: Eryptosis in hereditary spherocytosis and thalassemia: role of glycoconjugates. Glycoconj J 2010;27:717-722.

$\checkmark 9$ Felder KM, Hoelzle K, Ritzmann M, Kilchling T, Schiele D, Heinritzi K, Groebel K, Hoelzle LE: Hemotrophic mycoplasmas induce programmed cell death in red blood cells. Cell Physiol Biochem 2011;27:557-564.

$>10$ Föller M, Braun M, Qadri SM, Lang E, Mahmud H, Lang F: Temperature sensitivity of suicidal erythrocyte death. Eur J Clin Invest 2010;40:534-540.

11 Bhavsar SK, Gu S, Bobbala D, Lang F: Janus kinase 3 is expressed in erythrocytes, phosphorylated upon energy depletion and in- volved in the regulation of suicidal erythrocyte death. Cell Physiol Biochem 2011;27: 547-556.

12 Föller M, Mahmud H, Qadri SM, Gu S, Braun M, Bobbala D, Hocher B, Lang F: Endothelin $\mathrm{B}$ receptor stimulation inhibits suicidal erythrocyte death. FASEB J 2010;24: 3351-3359.

13 Qadri SM, Mahmud H, Lang E, Gu S, Bobbala D, Zelenak C, Jilani K, Siegfried A, Foller M, Lang F: Enhanced suicidal erythrocyte death in mice carrying a loss of function mutation of the Adenomatous Polyposis Coli gene. J Cell Mol Med 2011, E-pub ahead of print.

14 Bhavsar SK, Bobbala D, Xuan NT, Föller M, Lang F: Stimulation of suicidal erythrocyte death by alpha-lipoic acid. Cell Physiol Biochem 2010;26:859-868.

15 Ghashghaeinia M, Toulany M, Saki M, Bobbala D, Fehrenbacher B, Rupec R, Rodemann HP, Ghoreschi K, Rocken M, Schaller M, Lang F, Wieder T: The NFкB pathway inhibitors Bay 11-7082 and parthenolide induce programmed cell death in anucleated erythrocytes. Cell Physiol Biochem 2011;27:4554. 
16 Qadri SM, Kucherenko Y, Lang F: Beauvericin induced erythrocyte cell membrane scrambling. Toxicology 2011;283:24-31.

- 17 Lang E, Jilani K, Zelenak C, Pasham V, Bobbala D, Qadri SM, Lang F: Stimulation of suicidal erythrocyte death by bezethonium. Cell Physiol Biochem 2011;28:347-354.

- 18 Ghashghaeinia M, Bobbala D, Wieder T, Koka S, Bruck J, Fehrenbacher B, Rocken M, Schaller M, Lang F, Ghoreschi K: Targeting glutathione by dimethylfumarate protects against experimental malaria by enhancing erythrocyte cell membrane scrambling. Am J Physiol Cell Physiol 2010;299:C791-C804.

-19 Jilani K, Qadri SM, Lang E, Zelenak C, Rotte A, Bobbala D, Lang F: Stimulation of erythrocyte phospholipid scrambling by enniatin A. Mol Nutr Food Res 2011;55(suppl 2):S294S302.

-20 Eberhard M, Ferlinz K, Alizzi K, Cacciato PM, Faggio C, Foller M, Lang F: FTY720-induced suicidal erythrocyte death. Cell Physiol Biochem 2010;26:761-766.
21 Kucherenko YV, Bhavsar SK, Grischenko VI, Fischer UR, Huber SM, Lang F: Increased cation conductance in human erythrocytes artificially aged by glycation. J Membr Biol 2010;235:177-189.

22 Zelenak C, Föller M, Velic A, Krug K, Qadri SM, Viollet B, Lang F, Macek B: Proteome analysis of erythrocytes lacking AMP-activated protein kinase reveals a role of PAK2 kinase in eryptosis. J Proteome Res 2011;10: 1690-1697.

23 Nicolay JP, Gatz S, Lang F, Lang UE: Lithium-induced suicidal erythrocyte death. J Psychopharmacol 2010;24:1533-1539.

24 Bhavsar SK, Eberhard M, Bobbala D, Lang F: Monensin induced suicidal erythrocyte death. Cell Physiol Biochem 2010;25:745752 .
25 Jilani K, Qadri SM, Zelenak C, Lang F: Stimulation of suicidal erythrocyte death by oridonin. Arch Biochem Biophys 2011;511:1420.

-26 Eberhard M, Föller M, Lang F: Effect of phytic acid on suicidal erythrocyte death. J Agric Food Chem 2010;58:2028-2033.

$\checkmark 27$ Qadri SM, Bauer J, Zelenak C, Mahmud H, Kucherenko Y, Lee SH, Ferlinz K, Lang F: Sphingosine but not sphingosine-1-phosphate stimulates suicidal erythrocyte death. Cell Physiol Biochem 2011;28:339-346.

28 Lang E, Qadri SM, Zelenak C, Gu S, Rotte A, Draeger A, Lang F: Inhibition of suicidal erythrocyte death by blebbistatin. Am J Physiol Cell Physiol 2011;301:C490-C498.

29 Gatidis S, Meier A, Jilani K, Lang E, Zelenak C, Qadri SM, Lang F: Phlorhizin protects against erythrocyte cell membrane scrambling. J Agric Food Chem 2011;59:85248530.

>30 Mahmud H, Mauro D, Föller M, Lang F: Inhibitory effect of thymol on suicidal erythrocyte death. Cell Physiol Biochem 2009;24: 407-414. 